\title{
Pola Komunikasi Orang Tua \\ Dalam Pembentukan Kecerdasan Sosial \\ Di Kalangan Remaja Milenial
}

\author{
Fitri Sayidati Mukaromah, Akif Khilmiyah, Aris Fauzan \\ Universitas Muhammadiyah Yogyakarta \\ sayidatimukaromah@gmail.com
}

\begin{abstract}
This article aimed to describe communication pattern of parents among millennial adolescents and explain effective specific strategies of parental communication in shaping social intelligence among millennial adolescents. This is a field research that is a descriptive analytic study in nature with a qualitative approach that is ethnographic. Purposive sample was used and the data were collected through interview, observation, and document. The research credibility was done using the triangulation of source and method. The obtained data were then analyzed qualitatively using data reduction, data display, and conclusion drawing. The findings of the research are; firstly, the communication patterns used by family whose background is teachers in Bumirejo village are democratic and permissive communication patterns. Parents who implement democratic communication have communication characteristics such as having an open communication, cooperation, a mutual relation, and socializing with the society and motivating the adolescents. Secondly, in order to have a good communication in a family, some strategies done by the family whose background is teachersin Bumirejo village are such as by having a direct communication via a comfortable approach and by limiting their children' access in using mobile phones.
\end{abstract}

Keywords: Parental Communication Pattern, Social Intelligence, Millenni

\begin{abstract}
Abstrak
Artikel ini bertujuan untuk mendiskripsikan pola komunikasi orang tua di kalangan remaja milenial, dan untuk menjelaskan strategi tertentu yang efektif pada komunikasi orang tua dalam membentuk kecerdasan sosial di kalangan remaja milenial. Pendekatan di dalam penelitian adalah pendekatan kualitatif yang bersifat etnografi. Adapun sampel yang digunakan penulis adalah purposive sample. Pengumpulan data yang digunakan adalah wawancara, observasi, dan dokumentasi. Kredibilitas yang digunakan adalah
\end{abstract}

FOKUS : Jurnal Kajian Keislaman dan Kemasyarakatan Vol. 5, No. 1, 2020

LPPM Institut Agama Islam Negeri (IAIN) Curup - Bengkulu

p-ISSN 2548-334X, e-ISSN 2548-3358

DOI: $10.29240 /$ jf.v5i1.1366 
menggunakan triangulasi jenis source triangulaion dan methode triangulation. Data yang diperoleh kemudian dianalisis menggunakan analisis data kualitatif diantaranya reduksi data, penyajian data, dan yang terakhir adalah kesimpulan. Hasil dari penelitian ini adalah pertama, pola komunikasi yang digunakan pada keluarga guru di Desa Bumirejo adalah pola komunikasi demokratis dan pola komunikasi permisif. Orang tua yang menggunakan pola komunikasi demokratis memiliki ciri-ciri berkomunikasi dengan cara saling terbuka, melakukan kerja sama, adanya hubungan timbal balik, bersosialisasi dengan masyarakat,dan memotivasi diri anak remaja. Kedua, agar komunikasi di dalam keluarga terjalin dengan lancar maka diperlukan beberapa strategi yang digunakan oleh keluarga guru di Desa Bumirejo diantaranya dengan melakukan komunikasi langsung melalui pendekatan yang nyaman dan membatasi anak remaja dalam penggunaan teknologi telepon selular.

Kata kunci: Pola Komunikasi Orang Tua, Kecerdasan Sosial, Remaja Milenial

\section{Pendahuluan}

Remaja merupakan seorang anak yang mencoba untuk memahami dirinya sendiri dan kehidupan untuk mendapatkan jati dirinya. Komunikasi orang tua perlu dilakukan untuk mengontrol perilaku dari anaknya. ${ }^{1}$ Pada masa remaja sangat rentan terpengaruh dari lingkungannya. Maka pada masa remaja ini banyak berbagai bentuk penyimpangan sosial atau yang dikenal dengan kenakalan remaja. Maka dari itu orang tua perlu memberikan waktu untuk berbicara dengan anak terutama pada anak yang memiliki usia remaja. Sehingga anak remaja akan terbuka mengungkapkan permasalahan kepada orang tuanya.

Kecerdasan sosial suatu hal yang penting dalam kehidupan bermasyarakat. Beberapa orang yang sukses rata-rata memiliki kecerdasan sosial. Kecerdasan sosial adalah kemampuan menjaga hubungan baik antara diri kita sendiri dengan orang lain ataupun masyarakat. Manusia merupakan makhluk sosial. Membutuhkan bantuan orang lain. Tanpa orang lain kita tidak bisa menjalani kehidupan. Menjaga hubungan baik dengan masyarakat merupakan kewajiban bagi manusia. Hal pembentukan sosial anak yang paling utama adalah orang tua. Orang tua perlu membentuk sosial anak

Komunikasi yang tidak efektif remaja dengan orang tua akan menimbulkan pembentukan karakter yang tidak baik pada diri anak. Hal ini

${ }^{1}$ Sarwinda. 2018. Komunikasi keluarga Dalam Menanamkan Nilai-Nilai Keislaman Pada Rema Desa Tanjung Aman Lampung Utara.Jurnal Al-Bayan. Vol.24.No.1 JanuariJuni.h.100. 
akan menyebabkan remaja memiliki pemikiran dan sikap yang menyimpang. Ketika remaja sudah tertarik terhadap teknologi daripada komunikasi dengan orang tua, hal ini merupakan salah satu sumber peniruan bagi diri remaja tersebut. Diiringi dengan perkembangan teknologi juga berkembang ilmu pengetahuan. Jadi pada jaman milenial ini anak sekolah terutama remaja lebih banyak mendapatkan tugas dari sekolahannya. Adapun kasus lainnya, saat kegiatan masyarakat kebanyakan remaja milenial saat ini tidak peduli dan mengabaikannya. Mereka lebih mengedepankan bermain Handphonedan menghiraukan kegiatan tersebut. Ada beberapa remaja juga yang sama sekali tidak bersosialisasi dengan masyarakat sekitar terutama dalam kegiatan Islami, namun ketika kegiatan yang tidak Islami mereka muncul di masyarakat. Selain itu, terdapat remaja yang mengutamakan bermain game online sehingga remaja hanya mengurungkan diri di kamar setelah pulang sekolah sehingga kurangnya komunikasi dengan orang tua dan masyarakat. Hal ini diperkuat dengan pernyatakan kepala Desa Bangeran bahwasannya remaja di dusunnya tidak peduli dengan lingkungannya, mereka lebih mementingkan Handphone dan kepentingan sekolah daripada kegiatan masyarakat. $^{2}$

Oleh karena itu, alasan untuk penelitian ini agar para orang tua berintropeksi diri untuk membatasi anak didiknya menggunakan teknologi terutama Handphone dan selalu berkomunikasi secara langsung pada anak di setiap waktu sehingga akan mewujudkan anak remaja yang memiliki sikap sosial yang baik dengan lingkungannya. Orang tua juga memberikan teladan yang baik saat menggunakan teknologi dengan membatasinya supaya anak tidak menirunya.

Pertanyaan yang muncul yaitu Bagaimana pola komunikasi orang tua di kalangan remaja milenial? dan Apa strategi komunikasi orang tua yang digunakan dalam membentuk kecerdasan sosial di kalangan remaja milenial?. Adapun rumusan tujuan yaitu mendiskripsikan pola komunikasi orang tua di kalangan remaja milenial dan menjelasan strategi tertentu yang efektif pada komunikasi orang tua dalam membentuk kecerdasan sosial di kalangan remaja milenial.

Berdasarkan berbagai kepustakaan yang telusuri. Terdapat berbagai penelitian yang membahas mengenai pola komunikasi dalam membentuk kecerdasan sosial di kalangan remaja milenial. Hal ini akan mempermudah dalam mengklasifikasiannya. Adapun beberapa penelitian yang pernah dijumpai sebagai berikut:

${ }^{2}$ Wawancara dengan Bapak Arif Purwantoro. Kepala Desa Bangeran.11 Desember 
Penelitian Maria Anggita Karningtyas, Ida Wiendjarti, dan Agung Prabowo berjudul "Pola Komunikasi Interpersonal Anak Autis Di Sekolah Autis Fajar Nugraha Yogyakarta." ${ }^{3}$ Adapun tujuannya untuk mengetahui pola komunikasi antarpribadi anak autis dalam interaksi sosial dengan lingkungan. Hasilnya diantaranya proses komunikasi anak autis selalu spontan karena mereka lebih konsentrasi pada waktu lama, selanjutnya anak autis berkomunikasi dengan bahasa non verbal dan verbal. Mereka lebih cenderung menggunakan bahasa non verbal. Perbedaan dengan penulis, penelitian ini hanya menggunakan metode kualitatif eksploratif deskriptif serta lebih memfokuskan komunikasi pada anak autis.

Tri Endang Jatmikowati yang berjudul "Efektifitas Komunikasi Orang Tua Terhadap Kepribadian Intrapersonal Anak." ${ }^{4}$ Tujuannya mengetahui hubungan antara efektifitas komunikasi orang tua terhadap kepribadian intrapersonal anak. Hasilnya terdapat korelasi yang positif keduanya menunjukkan 0,900 dengan taraf kesesatan 5\%=0,514 dengan melakukan pembiasaan orang tua komunikasi kepada anak untuk mengembangakn kemampuan intrapersonal. Perbedaannya penelitian ini hanya menggunakan angket dan observasi dalam pengumpulan datanya serta lebih terfokuskan pada kepribadian intrapersonal anak.

Penelitian tersebut diperkuat dengan Muliaty Amin, Muh. Suhufi, dan Muh. Arif berjudul "Studi Kasus Dalam Menanggulangi Kenakalan Remaja Melalui Komunikasi Keluarga." Bertujuan untuk mengatasi kenakalan remaja dan faktor penghambat strategi komunikasi untuk keluarga. Hasilnya dengan menggunakan komunikasi tatap muka berupa dialog, membiasakan, dan memberikan perhatian. Hambatannya, faktor kepribadian dan lingkungan yang menggunakan telepon berlebihan. Pengumpulan data yang digunakan hanya wawancara dan memfokuskan pada komunikasi keluarga.

Adapun penelitian lain dari Clarisa Inda Oktaviana dan Hedi Pudjo Santosa berjudul "Pola Komunikasi Pengasuhan Ibu Single Parent.", Tujuannya memahami pola komunikasi yang dilakukan ibu single parent terhadap anak setelah perceraian. Menghasilkan bahwasannya waktu yang

${ }^{3}$ Karningtyas, Maria Anggita, Wiendijarti, Ida, dan Prabowo, Agung. 2009. Pola Komunikasi Interpersonal Anak Autis Di Sekolah Autis Fajar Nugraha Yogyakarta. Jurnal IlmuKomunikasi . Volume 7 Nomor 2 Mei-Agustus. h.120.

${ }^{4}$ Jatmiko, Tri Endang. 2018. Efektivitas Komunikasi Orang Tua Terhadap Kepribadian Intrapersonal Anak. Jurnal Anak Usia Dini dan Pendidikan ANak Usia Dini. Volume 4 Nomor 2 Agusutus. h. 1.

${ }^{5}$ Amin, Muliaty Amin, Muh Shuhufi, dan Muh Arif. 2019. Studi Kasus Dalam Menanggulangi Kenakalan Remaja Melalui Komunikasi Keluarga. No. 1.h. 12.

6 Oktaviana, Clarisa Inda Oktaviana dan Hedi Pudjo Santosa. 2019. Pola Komunikasi Pengasuhan Ibu Single Parent. Jurnal Ilmu Komunikasi. h.9. 
digunakan untuk komunikasi sedikit, namun hubungan diantaranya terjaga karena adanya keterbukaan dan percaya serta pandangan yang positif. Komunikasi pengasuhan kepada anak membentuk sikap flituristic dan self critism. Hal yang membedakan pengumpulan data menggunakan kualitatif analisis fenomenologi dan terfokus pada pengasuhan ibu single parent.

Penelitian Johannes Banner, Martin Gartmeier, Anne B, dkk berjudul "Differential learning gains in professional conversation training: A latent profile analysis of competence acquisition in teacher-parent and physicianpatient communication." "Bertujuan untuk mengetahui perbedaan omunikasi antara guru dengan orang tua dan dokter dengan pasiennya. Hasilnya identifikasi empat kelas menunjukkan hasil yang berbeda dalam 3 aspek kompetensi percakapan antara lain: penataan percakapan, memajukan solusi masalah dan membangun hubungan interpersonal yang positif. Perbedaan dengan penelitian, penelitian ini menggunakan metode pengumpulan kuantitatif dan membedakan komunikasi antara orang tua dengan guru dan pasien dengan dokter.

Martin Gartmeier, Markus Gebhardt, dan Benjamin Dotger berjudul "How do teacher evaluate their parent communication competence? Latent profiles and relationships to workplace behaviors." mengetahui kompetensi komunikasi antara orang tua dan guru. Hasilnya adalah terdapat empat kelompok guru: 24\% tinggi, 36\% tingkat sedang, 16\% komunikasi rendah. 24\% menunjukkan hal yang kuat pada pemecahan masalah komunikasi antara guru dengan orang tua. Perbedaannya penelitian ini menggunakan metode pengumpulan kuantitatif dan lebih memfokuskan pada komunikasi antara guru dengan orang tua wali.

Hal ini diperkuat dengan penelitian dari Claudia Schneider dan Madeleine Arnot yang berjudul "Transactional school home school communication: Addressing the mismatches between migrant parents and theachers views of parental knowledge, engagement and the barries to engagement." "Tujuannya untuk mengetahui sistem transaksi komunikasi

7 Bauer, Johannes dkk. 2018. Differential Learning Gains in Professional Conversation Training: A Latent Profile Analysis of Competence Acquisition in TeacherParent and Physician-Patient Communication. Learning and Individual Differences.Vol. 61 Januari. h. 1-10.

${ }^{8}$ Gartmeier, Martin Gartmeier, Gebhardt, Markus dan Dotger, Benjamin Dotger. 2016. How Do Teachers Evaluate Their Parent Communication Competence? Latent Profiles andRelationships to Workplace Behaviors. Teaching and Teacher Education .Vol. 55 April. h. 207-16.

${ }^{9}$ Schneider, Claudia Schneider dan Madeleine Arnot. 2018.Transactional SchoolHome-School Communication: Addressing the Mismatches between Migrant Parents' and Teachers' Views of Parental Knowledge, Engagement and the Barriers to Engagement.Teaching and TeacherEducation . Vol.75.Oktober .h.10-20.. 
antara sekolah dengan orang tua siswa yang memiliki bahasa Inggris sebagai EAL. Hasil yang didapat adanya kekurangan komunikasi antara sekolah dengan orang tua siswa serta tidak adanya kecocokkan orang tua dan persepsi guru. Ketidakcocokkan pengetahuan orang tua tentang sekolah anak mereka. Terdapat banyak hambatan orang tua dalam keterlibatannya di dalam sekolah. Perbedaannya penelitian ini menggunakan mex metods yaitu kualitatif dan kuantitatif.

Diperkuat dengan Lyne Smith, Patrick C.L.Heaven, dan Joseph Ciarrochi yang berjudul "Trait emotional intelligence, conflict communication patterns, and relationship satisfaction." mengetahui pentingnya kecerdasan emosional dan pola komunikasi dalam kepuasan hubungan. Hasilnya pasangan yang puas mereka yang tidak menghindari diskusi tentang hubungan masalah dan siapa yang memberi nilai tinggi. Pasangan yang puas lebih cenderung tingkat emosional serupa dengan pasangan dibandingkan pasangan yang tidak puas. Perbedaannya pada penelitian Lyne Smith menggunakan pengumpulan kuantitatif.

Tri Utami, Alfandra, dan Sri Artati Waluyati berjudul "Pengaruh Kecerdasan Emosional Terhadap Sikap Peduli Sosial Siswa di SMP Negeri 1 Palembang." 11 Bertujuan mengetahui kecerdasan emosional berpengaruh terhadap sikap peduli siswa. Adapun hasilnya signifikan antara kecerdasan emosional dan sikap peduli siswa sebesar 0,000 dan nilai a sebesar 0,05.Perbedaan dengan penelitian peneliti menggunakan pendekatan kuantitaif expost facto serta lebih memfokuskan pada peduli sosial.

Penelitian Ni Ketut Agustini, I Wayan Sujana, dan I Ketut Adnyana Putra berjudul " Korelasi Antara Kecerdasan Emosional dengan Interaksi Sosial Siswa Kelas V SD Gugus VI Pangeran Diponegoro Denpasar Barat." "2 Tujuannya mengetahui korelasi signifikan antara kecerdasan emosional dengan interaksi sosial siswa kelas V. Menghasilkan penelitian berupa adanya korelasi positif artinya semakin tinggi kecerdasan emosional semakin meningkat interaksi sosial siswa. Sebagai pendukung sumber belajar guru dalam meningkatkan kualitas pembelajaran untuk menghasilkan

${ }^{10}$ Smith, Lynne Smith, Patrick C.L. Heaven, dan Joseph Ciarrochi.2008.Trait Emotional Intelligence, Conflict Communication Patterns, and Relationship Satisfaction. Personality andIndividual Differences . Vol.44. No. 6. April.h. 1314-25.

${ }^{11}$ H, Tri Utamai, Alfiandra, dan Waluyati, Sri Artati. 2019. Pengaruh Kecerdasan Emosional Terhadap Sikap Peduli Sosial di SMP Negeri 1 Palembang. Jurnal Bhineka Tunggal Ika. Volume 6. Nomor 1. Mei.h.17.

${ }^{12}$ Agustini, Ni Ketut Agustini, I Wayan Sujana, dan I Ketut Adnyana Putra. 2019. Korelasi Antara Kecerdasan Emosional dengan Interaksi Sosial Siswa Kelas V SD Gugus VI Pangeran Diponegoro Denpasar Barat.Jurnal Pedagogi dan Pembelajaran . Vol.2. No. 1. h.131. 
siswa yang berkualitas. Perbedaannya penelitian ini menggunakan pendekatan kuantitaif ex post facto dan lebih mefokuskan pada interaksi sosial siswa.

Diperkuat penelitian mengenai kecerdasan sosial yang berjudul " Pengaruh Pola Asuh Ibu Terhadap Kecerdasan Sosial Ana Usia Dini di TK Kenanga Kabupaten Bandung Barat."13 Bertujuan untuk mengetahui pengaruh kecerdasan sosial anak usia dini berdasarkan pola asuh ibu yang dominan di keluarga. Diperoleh hasilnya bahwa pola asuh yang diberikan ibu untuk mendidik anak TK adalah pola asuh permisif dan demokratis dalam mengembangkan kecerdasan sosial anak di TK. Adapun perbedaannya penelitian ini menggunakan data pengumpulan wawancara dan observasi.

Penelitian Nana Suryana Nasution berjudul “ Pengembangan Kecerdasan Sosial Melalui Metode Pembelajaran Outdoor Education Dalam Pendidikan Jasmani." 14 Tujuannnya untuk mengetahui pengembangan kecerdasan sosial melalui metode pembelajaran outdoor education dalam pendidikan jasmani. Menghasilkan bahwa pendidikan jasmani merupakan aktivitas gerak perubahan fisik, mental, emosional, membentuk karakter dan pikiran. Sedangan kecerdasan sosial hadir sebagai pengayaan kurikulum adapun medianya alam. Perbedaannya pengumpulan data yang digunakan adalah kepustakaan dari berbagai teori.

Penelitian Hananel Rosenberg, Yaakov Ophir, dan Christa S.C. Asterhan yang berjudul "A virtual safe zone: Teachers supporting teenage student resilience through social media in times of war." 15 Bertujuan untuk mengetahui komunikasi guru siswa melalui teknologi jaringan sosial untuk mendukung ketahanan siswa. Hasilnya adanya kontak online dengan guru secara terus menerus berkontribuasi terhadap ketahanan. Tujuan utama komunikasi: memberikan dukungan emosional kepada siswa, mamantau kesulitan siswa, dan mempertahankan norma beradab. Perbedaannya penelitian ini hanya menggunakan metode pengumpulan wawancara terhadap 11 guru menengah.

Elika Nikooyeh Master of Arts, Fariba Zarani, dkk yang berjudul "The mediating role of social skills and sensation seeking in the relationship

${ }^{13}$ Robbiyah, Robbiyah, Ekasari, Diyan, dan Witarsa, Ramdhan Witarsa. 2018. Pengaruh Pola Asuh Ibu terhadap Kecerdasan Sosial Anak Usia Dini di TK Kenanga Kabupaten BandungBarat,. Jurnal Obsesi : Jurnal Pendidikan Anak Usia Dini. Vol. 2. No. 1. 10 Juni. h. 74.

${ }^{14}$ Nasution, Nana Suryana. 2018. Pengembangan Kecerdasan Sosial Melalui Metode Pembelajaran Outdoor Education Dalam Pendidikan jasmani. Vol 6. h. 8.

${ }^{15}$ Rosenberg, Hananel, Ophir, Yaakov dan Asterhan, Christa S.C. 2018. A Virtual Safe Zone: Teachers Supporting Teenage Student Resilience through Social Media in Times of War. Teaching and Teacher Education . Vol. 73 Juli 2018. h. 35-42. 
between trait emotional intelligence and scholl adjustment in Adolescents." Bertujuan untuk mengetahui peran mediasi ketrampilan sosial dan mencari sensani dalam hubungan antara sifat kecerdasan emosional dan penyesuaian sekolah pada gadis remaja. Hasilnya korelasi positif antara kecerdasan emosional sifat dan sekolah, sifat kecerdasan emosional dan ketrampilan sosial, dan ketrampilan sosial dan sekolah. Korelasi negatif antara kecerdasan emosi dan pencarian sensasi serta sensai dan penyesuaian sekolah. Data memberikan kecocokan peran mediasi ketrampilan sosial dan mencari sensasi dalam hubungan antara sifat kecerdasan emosional dan penyesuaian sekolah. Perbedaannnya penelitian ini menggunakan metode pengumpulan kuantitatif dengan sampel 400 siswa sekolah menengah.

Penelitian Hugo Peyre dkk yang berjudul "Sex differences in psychomotor development during the preschol period: A longitudinal study of the effects of environmental factors and of emotional, behavioral, and social functioning." ${ }^{, 17}$ Bertujuan untuk mengetahui sejauh mana perbedaan jenis kelamin dalam perkembangan psikomotorik selama periode prasekolah. Hasilnya anak perempuan menunjukkan ketrampilan motorik halus yang lebih baik daripada anak laki-laki. Anak perempuan juga menunjukkan kemampuan bahasa yang lebih baik pada 2 tahun dan 3 tahun tetapi tidak pada 5-6 tahun. Tidak menemukan perbedaan yang signifikan antara anak perempuan dan laki-laki dalam ketrampilan motorik kasar pada 2,3 atau 5-6 tahun.

Nicole Rogge, Insa Theesfeld, dan Carola Strassner berjudul "The Potential of Social Learning in Community Gardens and The Impact of Community Heterogeneity." 18 Tujuannya untuk mengetahui pembelajaran sosial yang terjadi di kebun masyarakat dan efek dari aspek heterogenitas kelompok pada sosial kebun. Adapun hasilnya pada potensi pembelajaran sosial menggambarkan kurva distribusi normal dan terdapat pengaruh negatif yang signifikan terhadap heterogenitas budaya dan pendidikan masyarakat potensi pembelajaran sosial kebun. Perbedaannya penelitian ini menggunkan pengumpulan data kuantitaif dan mengarah pada sosial di kebun.

${ }^{16}$ Nikooyeh, Elika Nikooyeh, Fariba Zarani, dan Jalil Fathabadi. 2017. The Mediating Role of Social Skills and Sensation Seeking in the Relationship between Trait Emotional Intelligence and School Adjustment in Adolescents. Journal of Adolescence. Vol. 59. Agustus .h. 45-50.

${ }^{17}$ Peyre, Hugo dkk.. 2019. Sex Differences in Psychomotor Development during the Preschool Period: A Longitudinal Study of the Effects of Environmental Factors and of Emotional, Behavioral, and Social Functioning,. Journal of Experimental Child Psychology. Volume 178 Februari. h. 369-84.

${ }^{18}$ Rogge,Nicole,,Theesfeld,Insa dan Strassner, Carola. 2019. The Potential of Social Learning in Community Gardens and the Impact of Community Heterogeneity. Learning, Culture and Social Interaction. Jounal homepage.h.1. 
Penelitian Meixuan Shao dkk berjudul "Distance Perception Warped by Social Relations: Social Interaction Information Compresses Distance." Tujuannya untuk mengetahui hubungan sosial terutama kualitas interaksi sosial mempengaruhi persepsi jarak. Hasilnya kerusakan memiliki efek besar pada orang lain, jarak dianggap lebih pendek daripada bantuan, dan niat tidak mempengaruhi persepsi jarak. Kualitas interaksi sosial menciptakan kendala sosial pada persepsi jarak. Perbedaannya penelitian ini menggunakan eksperimen dalam mencari datanya.

Hal itu diperkuat dengan penelitian Shannon Audley dan Svetlana Jovic berjudul "Making Meaning of Children's Social Interactions: The Value Tensions Among School, Classroom, and Peer Culture." 20 Tujuannya untuk menguji ketegangan nilai prososial dan menghargai diantara tiga pemangku kepentingan sekolah (misi sekolah, siswa, dan guru) untuk memahami bagaimana nilai-nilai dipertahankan, diciptakan, dan dibagikan dalam proses sosialisasi sekolah. Hasilnya meskipun siswa, guru, dan juga sekolah memegang nilai sosial interaksi termasuk rasa hormat terdapat ketegangan dalam bagaimana rasa hormat yang harus dilakukan. Mencerminkan perbedaan perkembangan sosial, kognitif, metakognitif pada siswa. Persamaannya dalam mencari data menggunakan metode wawancara, namun yang menjadi subjek penelitian ini adalah guru dan siswa di sekolah.

Diperkuat dengan penelitian Wouter Wolf dan Michael Tomasello berjudul "Watching a Video Together Creates Social Closeness Between Children and Adults." ${ }^{21}$ Bertujuan untuk mengetahui apakah anak kecil sudah terhubung dengan orang lain melalui gabungan perhatian. Adapun hasilnya baik pengalaman berbagi interaktif minimal maupun pengalaman berbagi non-aktif membuat anak-anak merasa lebih nyaman dengan novel dewasa. Interaksi perhatian bersama dan berbagi pengalaman secara umum, memainkan peran penting tidak hanya kognitif anak tetapi perkembangan sosial dan pembentukan sosial.Perbedaannya penelitian ini menggunakan metode pengumpulan eksperimen dan menggunakan subyek anak-anak yang berusia 2,5 tahun.

19 Shao,Meixuan dkk..2019.Distance Perception Warped by Social Relations: Social Interaction Information Compresses Distance.Acta Psychologica.Vol. 202. Januari. .h.1..

${ }^{20}$ Ausley, Shannon dan Jovic, Svetlan. 2019. Making Meaning of Children's Social Interactions: The Value Tensions among School, Classroom, and Peer Culture. Learning, Culture and Social Interaction.Vol. 24. Maret. h.1

${ }^{21}$ Wolf, Wouter dan Tomasello,Michael Tomasello. 2019.Watching a Video Together Creates Social Closeness between Children and Adults. Journal of Experimental Child Psychology. Vol. 189. Januari . h.1 
Diperkuat penelitian generasi milenial yang berjudul "Hubungan Prokrastinasi Akademik Dengan Kecerdasan Spiritual Generasi Milenial.",22 Bertujuan untuk mendidik mahasiswa yang tidak hanya taat kepada agama tetapi juga kebutuhan spiritual anak-anak yaitu kasih sayang, penghargaan, keamanan, pengembangan diri sehingga mencapai aktualisasi diri. Menghasilkan bahwa adanya keterbatasan dan kurangnya kontrol diri mengakibatkan prokratinasi akademik. Perbedaannya dari penelitian ini adalah hanya menggunakan metode pengumpulan data wawancara. Adapun persamaannya penelitian ini sama-sama membahas mengenai generasi milenial.

Penelitian I Kadek Ruminten dan Gusti Nyoman Mastini yang berjudul "Peningkatan Mutu Pendidikan Keluarga Pada Era Milenial." 23 Bertujuan untuk mengetahui peningkatan mutu pendidikan di dalam keluarga pada era milenial. Adapun hasilnya dalam percepatan era milenial saat ini mengalami berbagai macam perubahan terutama pada perubahan kebudayaan yang cepat, hal ini tidak hanya diajarkan di sekolah namun lebih pentingnya diajarkan di lingkungan keluarga. Menumbuhkan pendidikan karakter paling utama di dalam keluarga jika di lingkungan komunitas apalagi di era milenial ini anak akan terpengaruh oleh komunitasnya karena di komunitas anak hanya akan bermain dengan temannya. Perbedaanya penelitian ini menggunakan metode pengumpulan data kepustakaan. Persamaan penelitian ini dengan penelitian penulis sama dalam membahas mengenai generasi milenial.

Oleh karena itu, dari beberapa penelitian di atas bertujuan untuk melengkapi penelitian penulis mengenai pola komuniasi orang tua. Beberapa penelitian di atas lebih banyak membahas mengenai komunikasi yang dilakukan orang tua ataupun guru terhadap anak didiknya, penelitian mengenai kecerdasan sosial, interaksi sosial dan penelitian yang membahas generasi milenial. Penelitian penulis ini akan lebih memfokuskan pada pola komunikasi orang tua dalam membentuk kecerdasan sosial di kalangan remaja milenial. Hal ini digunakan untuk menghindari adanya plagiasi penelitian. Maka penelitian ini akan berbeda dengan sebelumnya.

${ }^{22}$ Chritanti, Yana Dwi dan Anwar, Rosyida Nurul. 2019. Hubungan Prokrastinasi Akademik Dengan Kecerdasan Spiritual Generasi Milenial. Jurnal Pedagogik. Vol. 06. No.01 Januari-Juni. h.32.

${ }^{23}$ Ruminten, I Kadek dan Mastini, Gusti Nyoman Mastini. 2019. Peningkatan MutuPendidikan keluarga Pada Era Milineal. Adi Widya: Jurnal Pendidikan Dasar . Volume 4, No. 2 Oktober. h. 184. 


\section{Metode Penelitian}

Jenis penelitian yang digunakan berupa penelitian lapangan (field research) yang bersifat deskriptif analitik. ${ }^{24}$ Data-data penelitian diperoleh dengan melakukan wawancara di beberapa sumber data yang ditentukan. Pendekatan kualitatif yang bersifat etnografi artinya penulis terlibat langsung di dalam kehidupan bermasyarakat sebagai bentuk pengamatan sikap serta perilaku sosial dan pengambilan data yang ada di lapangan. ${ }^{25}$ Populasi dalam penelitian ini adalah seluruh keluarga yang terdapat di Desa Bumirejo Kecamatan Lendah yang terdiri dari 3.074 KK. Yang terdiri dari laki-laki ada 4.610 orang sedangkan perempuan berjumlah 4.786 orang. Lokasi penelitian di Desa Bumirejo Lendah Kabupaten Kulon Progo dikarenakan lokasi yang jauh dari perkotaan.

Pengambilan sampel penelitian ini menggunakan teknik purposive sample adalah cara mengambil subjyek berdasarkan adanya tujuan tertentu. Sehingga dari populasi Kepala Keluarga (KK) di Desa Bumirejo hanya diambil orang tua yang memiliki pekerjaan sebagai guru. Tujuan penulis memilih guru dikarenakan guru itu sebagai penjaga nilai-nilai budaya dan transmiter peradaban. Adapun kriteria orang tua yang dijadikan sebagai informan adalah: suami atau istriyang memiliki anak remaja usia 13-18 tahun. Terdiri dari perempuan atau laki-laki duduk di kelas 1 SMP-3 SMA yang bertempat tinggal di Desa Bumirejo Kecamatan Lendah Kabupaten Kulon Progo. Sehingga terdapat 11 keluarga guru yang dijadikan sebagai sumber data diantaranya sebagai berikut:

Tabel 1: Keluarga Guru Yang Dijadikan Sumber Data

\begin{tabular}{|l|l|l|l|l|l|}
\hline No & Nama Suami & Pekerjaan & \multicolumn{1}{|c|}{$\begin{array}{c}\text { Nama } \\
\text { Istri }\end{array}$} & Pekerjaan & Alamat \\
\hline 1. & Subarjo & PNS Pemda & $\begin{array}{l}\text { Rusna } \\
\text { Syarifa }\end{array}$ & Guru & Jogahan \\
\hline 2. & Ismanto & Petani & $\begin{array}{l}\text { Siti } \\
\text { Sudaryatun }\end{array}$ & Guru & Tempel \\
\hline 3. & Slamet & Guru & $\begin{array}{l}\text { Farida } \\
\text { Aziz }\end{array}$ & Guru & Bangeran \\
\hline 4. & Yulianto & Guru & $\begin{array}{l}\text { Siti } \\
\text { Rahmawati }\end{array}$ & Guru & Jogahan \\
\hline
\end{tabular}

${ }^{24}$ Moleong, Lexy J.. 1999. Metode Penelitian Kualitatif. Bandung: PT Remaja Rosdakarya,. h. 3 .

${ }^{25}$ Kamarusdiana. 2019. Studi Etnografi Dalam Kerangka Masyaraat Dan Budaya. Jurnal Sosial dan Budaya Syar-i. Vol.6.No.2.h.116. 
106 | FOKUS : Jurnal Kajian Keislaman dan Kemasyarakatan Vol. 5, No. 1, 2020

\begin{tabular}{|l|l|l|l|l|l|}
\hline 5. & Sukardi & Wiraswasta & Tutik & Guru & Senik \\
\hline 6. & Kamsa & Guru & Surtinah & Guru & Senik \\
\hline 7. & Syahrofi & Guru & Suratinah & Guru & Panggang \\
\hline 8. & Sugiyono & Petani & Sumiarsih & Guru & Kalangan \\
\hline 9. & Pairin & Petani & $\begin{array}{l}\text { Murni } \\
\text { Rahayu }\end{array}$ & Guru & Kalangan \\
\hline 10. & Alm.Haryono & Jendral TNI & Sutimah & Guru & Bangeran \\
\hline 11. & $\begin{array}{l}\text { Lukman } \\
\text { Hakim }\end{array}$ & PNS Pemda & $\begin{array}{l}\text { Nur } \\
\text { Rohmah }\end{array}$ & Guru & Bangeran \\
\hline
\end{tabular}

Metode pengumpulan data; Pertama, wawancara digunakan untuk memperoleh data tentang pola komunikasi orang tua. Wawancara kepada orang tua untuk memperoleh data pola komunikasidan strategi yang digunakan untuk membentuk kecerdasan sosial remaja milenial.Kedua,observasi kepada remaja milenial bertujuan untuk memperoleh data kegiatan apa saja yang dilakukan di rumah dan lingkungannya untuk menunjang kecerdasan sosial. Adapun observasi orang tua untuk memperoleh data pola komunikasi melalui kegiatan yang dilakukan di rumah dan lingkungannya untuk menunjang pembentukan kecerdasan sosial remaja milenial. Ketiga,dokumentasi gambar kegiatan wawancara antara penulis dengan keluarga guru di Desa Bumirejo dan kegiatan remaja di Desa Bumirejo untuk menunjang pembentukan kecerdasan sosial di masyarakat.

Teknik yang digunakan menggunakan teknik triangulasi yaitu pengecekan data dan membandingkan data satu dengan lainnya untuk memperoleh kebenaran data sehingga memunculkan data yang lebih lengkap. Adapun analisis data yaitu reduksi data, penyajian data, dan kesimpulan.

\section{Hasil dan Pembahasan}

\section{Pola Komunikasi Orang Tua}

Komunikasi berasal dari Communication yaitu sama. Komunikasi terdapat kesamaan makna mengenai pesan yang disampaikan. Tujuannya untuk mengubah perilaku dan sikap seseorang agar pesan yang disampaikan dimengerti. ${ }^{26}$ Menurut Jalaluddin Rakhmat komunikasi adalah interaksi

\footnotetext{
${ }^{26}$ Gunawan, Hendri. 2013. Jenis Pola Komunikasi Orang Tua Dengan Anak perokok Aktif DI Desa Jembayan Kecamatan Loa Kulu Kabupaten Kutai Kertanegara. Jurnal Imu Komunikasi. h.222.
} 
antara manusia yang satu dengan lainnya. ${ }^{27}$ Sedangkan menurut Enjang pengertian komunikasi adalah sebagai alat sarana dan pasarana peyampaian pesan dari orang satu dengan orang lainnya. ${ }^{28}$ Definisi operasional komunikasi adalah cara berinteraksi menyampaikan informasi antara satu orang dengan orang lainnya secara keterbukaan tidak ada yang ditutupinya serta memiliki rasa empati dan kesabaran dan diakhiri dengan hubungan timbal balik antara keduanya.

Oang tua merupakan kunci dari pendidikan anak-anaknya. Pertama kali yang memahami anaknya memiliki kemampuan yang luar biasa di luar kemampuannya adalah orang tua. Orang tua tidak hanya memberikan layanan kepada anak, mengasuhnya, tidak hanya melahirkan anaknya, akan tetapi orang tua juga memberikan kasih sayang dan melindungi anakanaknya. ${ }^{29}$ Menurut Hibana S. Rahman terdapat beberapa hal yang penting di dalam peranan orang tua bagi pendidikan anak diantaranya ${ }^{30}$ :guru pertama dan utama bagi anaknya, sumber kehidupan, tempat bergantung, dan sumber kebahagiaan anak.

Pola merupakan bentuk atau corak. Pola komunikasi orang tua adalah bentuk interaksi yang dilakukan oleh orang tua ke anak ditandai dengan feedback (umpan balik). Diperkuat dengan pernyataan Soejanto pola komunikasi adalah gambaran proses komunikasi adanya keterkaitan antara satu komponen dengan komponen lainnya. ${ }^{31}$ Pola komunikasi orang tua akan berjalan lancar apabila di dalam keluarga terjalin hubungan keharmonisan antara ayah dan ibu serta anak-anaknya. Setelah penulis mengadakan penelitian terhadap keluarga guru di Desa Bumirejo. Maka diperoleh hasil jumlah secara keseluruhan keluarga guru yang menggunakan pola komunikasi dalam membentuk kecerdasan sosial anak remaja di Desa Bumirejo diantaranya sebagai berikut:

Tabel 2: Pola Komunikasi Keluarga Guru di Desa Bumirejo

\begin{tabular}{|c|c|c|c|c|c|}
\hline \multirow{2}{*}{ Keluarga } & \multicolumn{2}{|c|}{ Suami } & \multicolumn{2}{c|}{ Istri } & \multirow{2}{*}{ Pola } \\
\cline { 2 - 5 } & Guru & Swasta & Guru & Swasta & Komunikasi \\
\hline 1 & & $\sqrt{ }$ & $\sqrt{ }$ & & Demokratis \\
\hline 2 & & $\sqrt{ }$ & $\sqrt{ }$ & & Demokratis \\
\hline
\end{tabular}

27 Rakmat, Jalaluddin. 2011. Psikologi Komunikasi. Bandung: PT Remaja Rosdakarya. h.9.

${ }^{28}$ Enjang. 2009. Komunikasi Konseling. Bandung: NUANSA. h.16.

${ }^{29}$ Harahap, Asriana dan Nasution, Latif Kahpi. 2019. Pendidikan Dalam Keluarga. Junal Ilmu- Ilmu Sosial dan Keislaman. Vol. 4.No.4.h.168.

${ }^{30}$ Rahman, Hibana S. 2005. Konsep Dasar Pendidikan Anak Usia Dini. Yogyakarta: Cerdas Pustaka.h.145-146.

${ }^{31}$ Soejanto, Agoes. 2005. Psikologi Komunikasi. Bandung:PT Remaja.h.27. 
108 | FOKUS : Jurnal Kajian Keislaman dan Kemasyarakatan Vol. 5, No. 1, 2020

\begin{tabular}{|c|c|c|c|c|c|}
3 & $\sqrt{ }$ & & $\sqrt{ }$ & & Demokratis \\
\hline 4 & $\sqrt{ }$ & & $\sqrt{ }$ & & Demokratis \\
\hline 5 & & $\sqrt{ }$ & $\sqrt{ }$ & & Permisif \\
\hline 6 & $\sqrt{ }$ & & $\sqrt{ }$ & & Demokratis \\
\hline 7 & $\sqrt{ }$ & & $\sqrt{ }$ & & Demokratis \\
\hline 8 & & $\sqrt{ }$ & $\sqrt{ }$ & & Demokratis \\
\hline 9 & & $\sqrt{ }$ & $\sqrt{ }$ & & Demokratis \\
\hline 10 & - & - & $\sqrt{ }$ & & Demokratis \\
\hline 11 & & $\sqrt{ }$ & $\sqrt{ }$ & & Demokratis \\
\hline
\end{tabular}

Berdasarkan tabel 2 diperoleh kesimpulannya bahwa di dalam keluarga guru rata-rata menggunakan pola komunikasi demokratis. Kebanyakan dari keluarga guru tidak menyukai kegiatan yang memaksakan anak. Boleh anak melakukan sesuatu asalkan anak tersebut mengetahui komitmen yang dibuat di dalam keluarga. Di dalam keluarga guru ini juga tidak menyukai hal-hal yang akan membuat anak marah. Ketika anak membuat suatu kesalahan biasanya sebagai orang tua yang memiliki pendidikan hanya memberikan nasihat tanpa memarahi anak. Kecuali sesuatu hal yang sangat keras dilakukan oleh para orang tua yang memiliki profesi sebagai guru adalah menekankan mengenai kegiatan keagamaan terutama ibadah. Jangan sampai ibadah sholat lima waktu tertinggal akibat dari perkembangan teknologi HP.

Namun, hanya terdapat satu keluarga saja yang menggunakan pola komunikasi permisif. Hal ini juga diketahui pendidikan dari orang tuanya. Profesi dari ibunya adalah guru. Namun profesi dari bapaknya wiraswasta yang terkadang hanya menganggur di rumah saja. Apalagi pendidikan terakhir yang diperoleh oleh bapaknya hanya sampai tamat SMP. Pendidikan dari orang tua juga mempengaruhi cara mendidik anak dengan baik dan benar. Apalagi yang terkadang pengangguran membuktikan bahwa dalam mendidik anaknya hanya mengalir saja tanpa memperhatikan kegiatan anaknya. Anak remajanya pun tidak memiliki tujuan alhasil pulang sekolah hanya bermain game online dan bermain dengan teman-temannya sehingga tidak peduli dengan kegiatan belajar bahkan pada orang tuanya. Yang mana pada keluarga ini orang tua tidak mau peduli dengan anak remajanya.

\section{Pola Komunikasi Orang Tua ke Anak}

Terdapat tiga pola komunikasi orang tua terhadap anak diantaranya ${ }^{32}$ :

\footnotetext{
${ }^{32}$ Setyowati, Yuli. 2005. Pola Komunikasi Keluarga dan Perkembangan Emosi Anak (Studi Kasus Penerapan Pola Komunikasi Keluarga dan Pengaruhnya Terhadap
} 


\section{Pola Otoriter}

Orang tua yang otoriter akan melakukan peraturan-peraturan yang ketat yang harus dilakukan oleh anaknya. Pola otoriter tidak sehat karena bersifat satu arah. Anak tidak boleh memberikan pendapatnya.Orang tua membuat peraturan untuk kebaikan anak namun orang tua tidak melihat efek yang ditimbulkan dari peraturan yang kaku tersebut. Namun, dari beberapa responden penelitian penulis di Desa Bumirejo dari keluarga guru tidak ada yang menggunakan pola komunikasi otoriter kepada anaknya. Responden keluarga guru lebih banyak memberikan kebebasan berpendapat kepada anaknya dari pada memberikan kekangan terhadap berbagai macam aturan yang memaksa anaknya.

\section{Pola Demokratis}

Orang tua otoritatif merupakan orang tua yang memberikan bimbingan namun tidak mengatur serta membolehkan anak untuk berpendapat. Pola otoritatif ini pola yang tepat digunakan. Pola ini menghasilkan remaja yang percaya diri, mandiri, konsep diri yang positif sehingga tidak akan mencari perhatian dari luar. Kemandirian anak mereka hargai. Bertujuan untuk melatih kemandirian anak, menyelesaikan permasalahan, keberanian, dan tanggung jawab. beberapa responden yang dipilih dari keluarga guru yang ada di Desa Bumirejo rata-rata keluarga guru menggunakan pola demokratis untuk mendidik anaknya terutama saat berkomunikasi. Tidak mendidik anaknya dengan keras kecuali mendirikan sholat lima waktu dan memberikan komitmen kepada anak agar anak memiliki tanggung jawab. Hal yang akan didapatkan dari pola demokratis ini anak akan memiliki sikap santun, patuh, berani, bertanggung jawab, dan memilki prestasi tinggi. Beberapa responden menurut hasil observasi penulis, responden tersebut memiliki anak yang mempunyai prestasi tinggi terlihat dari tabel pendidikan di atas rata-rata anak dari responden menempuh pendidikan di sekolah favorit di daerahnya. Kemudian anaknya memiliki sikap santun kepada penulis saat penulis datang. Hal ini menunjukkan bahwa orang tua berhasil dalam mendidik anaknya agar anak menjadi orang yang patuh, santun, dan pintar. Seperti salah satu responden di bawah ini yang mengatakan sebagai berikut.

"Saya itu tidak memberikan aturan-aturan kepada anak mbak. Namun ketika mengenai hal sholat saya memang benar-benar mendidik dengan keras. Karena sholat itu penting sekali. Alhamdulilah anak saya juga penurut tidak suka keluar malam.,"33

\footnotetext{
Perkembangan Emosi Anak Pada keluarga Jawa.Jurnal Ilmu Komunikasi. Vol.2.No.1.Juni.h.74.

${ }^{33}$ Wawancara dengan Ibu Rusna Syarifa, 13 Desember 2019.
} 
Pada pernyataan di atas mengatakan bahwa Rus (45) tidak menyukai memberikan aturan-aturan yang keras kecuali aturan mengenai hal sholat. Anak dari Rus (45) yang masih remaja juga selalu menurut kalau diperintah.Pernyataan dari Rus (45) sama dengan pernyataan dari Yul (50) bahwasanya tidak menyukai hal-hal yang selalu menurunkan jiwa anak seperti marah-marah kalau anak mempunyai kesalahan.

"Dalam memberikan aturan kepada anak yang utama hanya mengenai ibadah shalat kepada Allah. Ketika waktu shalat magrib dan isyak TV dan HP harus dimatikan dan bersama-sama melakukan kewajiban sebagai umat Islam." 34

Yul (50) mengatakan bahwasannya ketika sedang shalat magrib dan isyak TV dan HP harus dimatikan dan fokus untuk beribadah kepada Allah SWT.

\section{Pola Permisif}

Oang tua permisif adalah orang tua yang mendidik dan menerima pendapat anak dan cenderung pasif ketika berhadapan dengan permasalahan. Orang tua tidak menuntut karena anak akan berkembang secara alamiah. Pola ini memberikan kebebasan kepada anak untuk melakukan kegiatan serta tidak mengikat antara orang tua dan anak. Hanya ada satu responden keluarga guru di Desa Bumirejo yang menggunaan pola ini. Seperti pernyataan responden di bawah ini.

“Anak sekarang kan susah ya mbk. Kalau diatur semakin melonjak. Saya terserah anak saja kalau dia pergi saya ijinkan. Kadang nylonong juga pergi kemana. Rada susah mbak anak saya."

Suk (50) mengatakan memberikan kebebasan sepenuhnya terhadap anak-anaknya. Tidak memberikan aturan yang memaksa. Dikarenakan kalau anak diatur akan melonjak perilakunya.

\section{Keterbukaan Orang Tua}

Keterbukaan yang dilakukan oleh keluarga guru di Desa Bumirejo bahwasaanya tidak semua keluarga guru memiliki keterbukaan kepada anggota keluarganya. Kemudian antara suami dan istri diperlukan kerja sama dalam mendidik anak jangan sampai anak hanya mencintai bapak maupun ibunya tanpa kedua-duanya. Keluarga guru yang menggunakan pola demokratis memiliki keterbukaan kepada anggota keluarganya. Anak remajanya selalu menceritakan permasalahan kepada orang tuanya tanpa menutup-nutupinya. Bahkan apabila seorang ibu melekat dengan anak

\footnotetext{
${ }^{34}$ Wawancara dengan Bapak Yuli, 13 desember 2019.

${ }^{35}$ Wawancara dengan Bapak Sukardi, 14 Desember 2019.
} 
remaja laki-laki. Anak tersebut akan percaya kepada ibunya dan menceritakan semua kejadian sampai hal yang terkecil seperti mempunyai teman dekat. Seorang ibu harus mengasyikan di hadapan anaknya. Supaya anakpun akan terbuka mengenai masalah pribadinya. Diantara orang tua dan anak tidak ada yang ditutupinya. Ditambah dengan pernyataan Far (45).

"Anak saya sangat terbuka dengan saya permasalahan di sekolah diceritakan. Selain itu teman dekatnya sering cerita dengan saya.Karena saya berkomitmen harus ada komunikasi anak dengan orang tua kalau tidak ada malah cerita sama orang lain akhirnya nanti ndak dijerumuskan. Kemudian informasi di sekolah seperti nilai itu cerita dengan saya. Sekecil apapun anak saya cerita." 36

Pernyataan di atas mengatakan diperlukan komitmen untuk berkomunikasi secara terbuka dengan anak. Diperkuat dengan hasil observasi penulis dari keluarga Far (45) dan Mar (48) sangat ramah dalam menanggapi pertanyaan dari penulis. ${ }^{37}$

Berbeda dengan keluarga yang menggunakan pola permisif. Di dalam keluarga tersebut tidak terdapat keterbukaan dari anak remajanya kepada orang tua. Orang tua tidak mengetahui permasalahan yang ada pada diri anak setiap hari dikarenakan anak lebih menyukai teman-temannya dan juga bermain game online. Pada pola ini orang tua tidak peduli kepada perilaku anak remajanya bahkan orang tua pasrah dengan kondisinya saat ini. Masalah mengenai pendidikan di sekolah dan juga teman dekat orang tua tidak mengetahuinya bahkan orang tua tidak tahu anak tersebut bermain kemana dengan teman-temannya. Seperti keluarga Suk (50) dan Tut (50). Tut (50) mengatakan bahwasannya anak remajanya tidak pernah terbuka sama. sekali dengannya. Bahkan masalah pribadi masalah sekolahpun tidak diberitahu. Yang dilakukan hanya bermain HP dan game online. ${ }^{38}$ Diperkuat dengan kedatangan penulis ke rumahnya bahwa keluarga dari Suk (50) dan Tut (50) tidak ramah bahkan penulis terkadang dicuekin saat meminta data wawancara dari keluarga ini. ${ }^{39}$

\section{Hambatan Komunikasi}

Terdapat hambatan ketika berkomunikasi dengan lainnya diantaranya: Pertama, Hambatan internal yaitu berasal dari diri individu misalnya seseorang mengalami pendengaran maka komunikasinya akan terganggu.

2019.

${ }^{36}$ Wawancara dengan Ibu Farida Aziz, Istri Bapak Marsud Slamet, 13 Desember

${ }^{37}$ Observasi di Rumah Ibu Farida Aziz dan Bapak Marsudi Slamet. 13 desmebr 2019.

\footnotetext{
${ }^{38}$ Wawancara dengan Ibu Tutik, Istri Bapak Sukardi, 14 Desember 2019.

${ }^{39}$ Observasi di Rumah Bapak Sukardi dan Ibu Tutik, 14 Desember 2019.
} 
Kedua, Hambatan eksternal yaitu berasal dari luar individu misalkan lingkungan sekitar dan media masa seperti jika ada seseorang yang bermain Handphone akan lebih mementingkan daripada berkomunikasi dengan orang lain. Apalagi di era teknologi saat ini komunikasi seseorang mulai terhambat. Kebanyakan orang lebih menyukai berinteraksi lewat Handphone daripada tatap muka. ${ }^{40}$

Diketahui di dalam keluarga yang orang tua memiliki pekerjaan guru dengan karir tinggi hambatan dalam berkomunikasi adalah kesibukan masing-masing antara anggota keluarga. Apalagi jika orang tuanya memiliki pendidikan yang tinggi, anak remajanya aktif dalam kegiatan yang ada di sekolah. Sehingga di dalam keluarga tersebut komunikasinya terhalang dengan kesibukkan dari masing-masing anggota keluarga.

Berbeda dengan orang tua yang salah satu bekerja menjadi guru yang satunya hanya berpendidikan SMP. Hambatan berkomunikasi dengan anak remajanya tidak mengenai kesibukkan masing-masing anggota keluarga. Akan tetapi hambatan saat berkomunikasi terutama pada orang tua yang menggunakan pola permisif adalah penggunaan HP yang tidak teratasi. Menurut keluarga ini penggunaa HP sangat mempengaruhi komunikasi di dalam keluarga.

\section{Kerja Sama}

Berdasarkan pernyataan di atas mengenai kerja sama di dalam keluarga. Orang tua yang menggunakan pola komunikasi permisif, anaknya tidak mau membantu pekerjaan dari orang tuanya. Bahkan pada keluarga ini anak remaja tidak peduli dengan semua pekerjaaan yang dilakukan oleh orang tuanya. Keluarga ini berbeda dengan keluarga yang orang tuanya memiliki pekerjaan dengan posisi dan pendidikan tinggi. Pada keluarga seperti ini akan memiliki anak remaja yang giat dalam belajar dan aktif dalam kegiatan organisasi di sekolahannya. Sehingga anak remaja pada keluarga seperti anak rata-rata tidak mau membantu pekerjaan orang tua dan lebih mementingkan pendidikan di sekolahannya dengan belajara secara giat.

Berbeda lagi dengan keluarga yang salah satunya menjadi guru yang satunya hanya lulusan SMP dan bekerja menjadi seorang wiraswasta. Pada keluarga ini tingkat kerja sama yang dilakukan dengan anggota keluarga bagus sekali. Keluarga ini memiliki anak remaja yang tanggap dan memperhatikan orang tuanya. Ditambah lagi pada keluarga ini, anak remajanya tidak aktif dalam kegiatan di sekolahannya dan memiliki prestasi yang tidak terlalu tinggi sehingga waktu di rumah untuk orang tuanya

\footnotetext{
${ }^{40}$ Khairani, Makmun. 2015. Psikologi Komunikasi Dalam Pembelajaran. Yogyakarta: Anggota IKAPI. h.111-112.
} 
banyak. Akan tetapi terdapat keluarga yang memiliki anak remaja dengan sifat empati yang tinggi terhadap orang tuanya di tengah-tengah kesibukkan tugas sekolah dan juga perkembangan teknologi. Pernyataan dari Sit (52).

"Anak saya kalau liburan bersih-bersih di rumah. Saling membantu antara adik dan kakak juga orang tua. Ada yang nyuci piring ada yang menyapu." 41

Pernyataan Sit (52) di atas bahwasannya di dalam keluarga antara anggota keluarga diperlukan kerja sama untuk mempermudah pekerjaan dengan cara membagi tugas dengan anak-anaknya. Hal ini juga dilakukan di dalam keluarga Rus (45) dan Sub (40).

"Anak saya alhamdulilah saling kerja sama dengan saya. Ketika adeknya nangis dihibur. Saya dengan bapaknya kan pulang sore. Jadi anak saya yang besar membantu adeknya yang masih kecil." ${ }^{42}$

\section{Bersosialisasi dengan masyarakat}

Pernyataan beberapa keluarga guru diperkuat dengan observasi yang dilakukan oleh penulis. Rata-rata anak remaja yang orang tuanya guru dan memiliki prestasi tinggi di sekolahnya tidak pernah mengikuti kegiatan di masyarakat. Penulis menyimpulkan di dalam bersosialisasi seorang anak remaja tergantung perilaku orang tuanya. Karena seorang anak pasti akan mengikuti perilaku dan sifat yang diturunkan oleh orang tuanya. Berbeda dengan keluarga yang hanya satu menjadi guru yang satunya bekerja sebagai wiraswasta. Anak remajanya aktif dalam kegiatan organisasi yang ada di sekolahannya. Pada anak remaja di keluarga seperti ini rata-rata memiliki kemampuan kecerdasan yang tidak tinggi dan tidak terlalu menekankan pendidikan sehingga terlalu banyak waktu luang pada remaja ini untuk bersosialisasi dengan lingkungan masyarakat sekitar.

\section{Hubungan Timbal Balik}

Pada komunikasi antara orang tua dan anak diperlukan hubungan timbal balik. Berdasarkan penelitian yang penulis lakukan pada beberapa responden keluarga guru di Desa Bumirejo. Keluarga yang menggunakan pola komunikasi demokratis menggunakan komunikasi yang bagus antara orang tua dan anak remajanya. Pada keluarga ini anak remajanya juga ketika diajak untuk berkomunikasi memberikan jawaban yang semestinya. Bahkan apabila orang tua terutama ibu memilii kedekatan yang sangat erat kepada anak laki-laki.

\footnotetext{
${ }^{41}$ Wawancara dengan Ibu Situ Sudaryatun, Istri Bapak Ismanto, 13 Desember.

${ }^{42}$ Wawancara dnegan Ibu Rusna Syarifa, 13 Desember 2019.
} 
Jika pada keluarga yang menggunakan pola komunikasi permisif pada keluarga Tut (50) dan Suk (50) yang memiliki anak remaja laki-laki yang sedang menempuh pendidikan pada bangku SMK. Menurut pernyataan dari Tut (50) anaknya tersebut jarang berbicara dengan orang tuanya. Bahkan ketika orang tua berbicara anaknya tidak peduli dan mengacuhkan pembicaraan dari orang tuanya itu. ${ }^{43}$ Tidak ada hubungan timbal balik pada pola komunikasi permisif. Orang tua yang tidak peduli dan kurang memberikan kasih sayang kepada anak. Selain itu anak remaja yang sudah dipengaruhi oleh lingkungan dan teknologi. Diperkuat dengan observasi yang dilakukan oleh penulis ketika penulis datang tanggapan maupun jawaban ketika mencari data dari keluarga ini acuh tak acuh dan tidak peduli dengan kedatangan penulis. ${ }^{44}$

\section{Memotivasi Diri}

Dibutuhkan komunikasi setiap hari antara orang tua dan anak. Adanya komunikasi tersebut akan menumbuhkan motivasi diri pada anak remaja. Motivasi memiliki arti kekuatan yang terdapat pada setiap individu yang mengakibatkan seseorang individu melakukan suatu perbuatan. Ketika memberikan motivasi tidak dilakukan secara langsung namun pemberian motivasi bisa dilakukan dengan tingkah laku yang terdiri dari dorongan dan rangsangan yang menjadi pembangkit munculnya perbuatan tingkah laku individu. ${ }^{45}$ Motivasi diri ini biasa dilakukan pada keluarga yang memiliki anak berprestasi. Orang tua yang memiliki prestasi tinggi yang akan membuat anak menjadi termotivasi untuk meniru orang tuanya. Berbeda dengan keluarga yang menggunakan pola permisif. Sehingga anak remajanya pun tidak memiliki tujuan yang bagus karena orang tuanya pun yang tidak peduli dengan kondisi dan kegiatan anak remaja. Bahkan orang tua dari keluarga ini tidak mengetahui pendidikan anaknya. Tidak ada motivasi diri di dalam keluarga dengan pola komunikasi permisif.

\section{Strategi Komunikasi}

Ada beberapa cara untuk mengatasinya menurut Makmun Khairani diantaranya: Gunakan umpan balik (ketika sedang berbicara dengan individu lain, menjawab pembicaraan individu lainnya dengan benar. Saat anak berbicara kepada orang tua, orang tua memberikan jawaban yang tepat dan baik). Pahami perbedaan individu (sebelum berbicara perlu dipahami latar belakang seseorang sehingga bisa menggunakan taktik komunikasi yang sesuai.Anak jaman sekarang akan jauh berbeda dengan anak dahulu).

${ }^{43}$ Wawancara dengan Ibu Tutik. Istri dari Bapak Sukardi. 14 Desember 2019.

${ }^{44}$ Observasi di Rumah Ibu Tutik dan Bapak Sukardi. 14 Desember 2019.

${ }^{45}$ Uno, Hamzah B. 2011. Teori Motivasi \& Pengukurannya. Jakarta: PT Bumi Aksara.h.3. 
Komunikasi langsung (saat berbicara dibiasakan berkomunikasi secara tatap muka agar bisa mengetahui bahasa dan gerak gerik tubuhnya). Gunakan bahasa yang mudah dan sederhana (saat berkomunikasi gunakan bahasa yang mudah untuk dipahami dan sederhana. Di era milenaial saat ini selain perkembangan teknologi yang maju akan tetapi perkembangan bahasapun sudah semakin berkembang pesat). ${ }^{46}$

Kesimpulan di dalam strategi berkomunikasi untuk membentuk kecerdasan sosial anak remaja saat ini kebanyakan dari keluarga guru di Desa Bumirejo ini memilih penggunaan strategi komunikasi secara langsung dengan memahami keadaan dan kondisi anak remaja. Kesebelas keluarga di Desa Bumirejo ke sembilannya lebih menggunakan komunikasi dengan pendekatan yang nyaman kepada anak remajannya. Hal ini dilakukan karena anak remaja saat ini sudah berbeda dengan dahulu. Remaja sekarang memiliki ego yang tinggi. Orang tua perlu memahami sifat dan keadaan anak sebelum diajak untuk berkomunikasi. Orang tua juga harus paham bahwa anak milenial saat ini hatinya mudah tersinggung dan selalu menggunakan emosi yang tinggi. Diperlukan pendekatan yang nyaman saat mulai berkomunikasi. Sementara dua keluarga dari sebelas keluarga guru di Desa Bumirejo memilih strategi dengan membatasi anak remajanya menggunakan teknologi HP. Orang tua perlu membatasi anak remaja untuk menggunakan HP agar komunikasi dengan anak remaja bisa berjalan dengan lancar. Namun orang tua juga harus mengintropesi dirinya untuk tidak bermain HP secara berlebihan. Agar anak juga mencontoh apa yang dilakukan oleh orang tuanya. Antara anak dan orang tua memiliki komitmen dalam menggunakan HP.

\section{Kecerdasan Sosial}

Kecerdasan adalah kemampuan yang dimiliki oleh seseorang. Menurut Robiyah kecerdasan sosial adalah kemampuan dalam memotivasi diri, mengendalikan dirinya, kemampuan dalam berempati, dan membina hubungan baik dengan orang lain. ${ }^{47}$ Menurut Nana Suryana Nasution kecerdasan sosial adalah kemampuan seseorang dalam bergaul dengan masyarakat serta berinteraksi sosial dengan orang di lingkungannya. Kecerdasan sosial merupakan akar dari kecerdasan emosional. Orang yang memiliki tingkat kecerdasan sosial tinggi tidak sulit untuk memulai interaksi

${ }^{46}$ Khairani, Makmun. Psikologi...h. 118-119.

${ }^{47}$ Robbiyah, Robbiyah, Ekasari, Diyan, dan Witarsa, Ramdhan Witarsa. 2018. Pengaruh Pola Asuh Ibu terhadap Kecerdasan Sosial Anak Usia Dini di TK Kenanga Kabupaten BandungBarat,. Jurnal Obsesi : Jurnal Pendidikan Anak Usia Dini. Vol. 2. No. 1. 10 Juni. h.78. 
dengan orang lain. ${ }^{48}$ Menurut Goleman dalam jurnal Eki Dwi Putra dan Harlina Nurtjahjanti kecerdasan sosial adalah kemampuan seseorang dalam berinteraksi dan memahami orang lain. Selain itu, Albercht mengemukakan kecerdasan sosial adalah kemampuan bergaul secara baik dan mengajaknya untuk bekerja sama. ${ }^{49}$ Dapat disimpulkan, definisi konseptual kecerdasan sosial sebagai berikut: kecerdasan sosial adalah kemampuan seseorang dalam berinteraksi dengan lingkungannya dengan cara memahami orang lain, memotivasi diri dan bekerja sama di dalam kehidupan sehari-hari.

\section{Remaja Milenial}

Generasi milenial berasal dari millennials yang diciptakan oleh penulis Amerika yaitu Neil Howe dan William Strauss. Menciptakan pada tahun 1987 saat anak-anak lahir 1982 masuk pra sekolah. Pada saat itu media menyebut kelompok ke milenium baru pada tahun 2000. Masa muda milenial saat ini mudah tergoda terhadap materi yang membawa arus kepada kebebasan sehingga mereka tidak mau diatur. ${ }^{50}$ Berbagai macam generasi memiliki karakteristik yang berbeda-beda. Hal itu ditentukan oleh perubahan demografik. Baby boomers merupakan generasi yang lahir pada tahun 19461964. Adapun generasi yang lahir pada tahun 1965-1979 disebut sebagai generasi X. Sedangkan generasi Y merupakan generasi yang lahir diantara tahun 1980-2000. Generasi milenial yaitu generasi yang lahir pada saat mulai berkembangnya internet. Generasi $\mathrm{Z}$ yaitu generasi yang lahir setelah generasi milenial. $^{51}$

\section{Kesimpulan}

Hasil yang diperoleh dari pembahasan diantaranya: Pertama, Berkaitan dengan pola komunikasi orang tua dalam membentuk kecerdasan sosial di kalangan remaja milenial, penulis akan memberikan kesimpulaannya bahwa di dalam keluarga guru di Desa Bumirejo terdapat dua pola komunikasi yang digunakan yaitu pola komunikasi demokratis dan pola komunikasi permisif. Orang tua yang menggunakan pola komunikasi

\footnotetext{
${ }^{48}$ Nasution, Nana Suryana. 2018. Pengembangan Kecerdasan Sosial Melalui Metode Pembelajaran Outdoor Education Dalam Pendidikan jasmani. Vol 6. h.78.

${ }^{49}$ Putra, Eki Dwi dan Nurthahjanti, Harlina. 2017. Hubungan Antara Kecerdasan Sosial Dengan Organizational Citizenship Behavior Pada Karyawan PT Telkom Indonesia Regional IV Jawa Tengah dan Di Yogyakarta. Jurnal Empati. Volume 6.No.4 Oktober. h.216.

${ }^{50}$ Chritanti, Yana Dwi dan Anwar, Rosyida Nurul. 2019. Hubungan Prokrastinasi Akademik Dengan Kecerdasan Spiritual Generasi Milenial. Jurnal Pedagogik. Vol. 06. No.01 Januari-Juni. h.34.

${ }^{51}$ Fatmawati, Nur Ika. 2019. Literasi Digital, Mendidik Anak Di Era Digital Bagi Orang Tua Milenial. Jurnal Politik dan Sosial Kemasyarakatan. Vol. 11 No. 2 Agustus. h. 125 .
} 
demokratis memiliki ciri-ciri berkomunikasi dengan cara saling terbuka, melakukan kerja sama, adanya hubungan timbal balik, bersosialisasi dengan masyarakat, dan memotivasi diri anak remaja. Kedua, Agar komunikasi di dalam keluarga terjalin dengan lancar maka diperlukan beberapa strategi yang digunakan oleh keluarga guru di Desa Bumirejo diantaranya dengan melakukan komunikasi langsung melalui pendekatan yang nyaman dan membatasi anak remaja dalam penggunaan teknologi HP.

Berdasarkan dari hasil kesimpulan di atas, penulis akan memberikan beberapa saran sebagai berikut: Pertama, Bagi Orang Tua Guru di Desa Bumirejo agar lebih meluangkan waktu untuk berkomunikasi dengan anggota keluarga. Kurangi kesibukkan di sekolah. Berikan waktu untuk bersama, berkumpul, dan berbicara kepada anak. Ikutkanlah anak remaja dalam kegiatan organisasi di masyarakat supaya anak mengenal dengan lingkungan sekitar. Kedua, Bagi istri guru dan suami wiraswasta di Desa Bumirejo. Tingkatkan kembali dalam memotivasi anak saat berkomunikasi dengan anggota keluarga. Agar anak juga peduli dengan prestasinya di sekolah. Batasilah anak dalam penggunaan teknologi HP. Agar anak tidak kecanduan. Ketiga, Bagi istri guru single parent. Gunakan waktu yang lebih dengan memberikan kasih sayang dan perhatian kepada anak remaja agar anak juga tidak merasa kehilangan seorang ayah dalam kehidupannya. Gunakan waktu setiap hari untuk berkomunikasi supaya anak mengutarakan permasalahan kepada ibunya. Keempat, Bagi orang tua yang menggunakan pola komunikasi permisif. Intropeksi dirilah karena perilaku anak adalah cerminan dari dirimu sendiri. Perbaikilah komunikasi kamu dengan anak. Berikan perhatian dan kasih sayang yang penuh kepada anak agar anak merasa diperhatikan dan lebih nyaman untuk berbicara kepada orang tuanya.

\section{Daftar Pustaka}

Agustini, Ni Ketut Agustini, I Wayan Sujana, dan I Ketut Adnyana Putra. 2019. Korelasi Antara Kecerdasan Emosional dengan Interaksi Sosial Siswa Kelas V SD Gugus VI Pangeran Diponegoro Denpasar Barat.Jurnal Pedagogi dan Pembelajaran . Vol.2. No. 1.

Amin, Muliaty Amin, Muh Shuhufi, dan Muh Arif. 2019. Studi Kasus Dalam Menanggulangi Kenakalan Remaja Melalui Komunikasi Keluarga. No. 1.

Ausley, Shannon dan Jovic, Svetlan. 2019. Making Meaning of Children's Social Interactions: The Value Tensions among School, Classroom, and Peer Culture. Learning, Culture and Social Interaction.Vol. 24. Maret. 
Bauer, Johannes dkk. 2018. Differential Learning Gains in Professional Conversation Training: A Latent Profile Analysis of Competence Acquisition in Teacher-Parent and Physician-Patient Communication. Learning and Individual Differences.Vol. 61 Januari.

Chritanti, Yana Dwi dan Anwar, Rosyida Nurul. 2019. Hubungan Prokrastinasi Akademik Dengan Kecerdasan Spiritual Generasi Milenial. Jurnal Pedagogik. Vol. 06. No.01 Januari-Juni.

Fatmawati, Nur Ika. 2019. Literasi Digital, Mendidik Anak Di Era Digital Bagi Orang Tua Milenial. Jurnal Politik dan Sosial Kemasyarakatan. Vol. 11 No. 2 Agustus.

Gartmeier, Martin Gartmeier, Gebhardt, Markus dan Dotger, Benjamin Dotger. 2016. How Do Teachers Evaluate Their Parent Communication Competence? Latent Profiles andRelationships to Workplace Behaviors. Teaching and Teacher Education .Vol. 55 April.

Gunawan, Hendri. 2013. Jenis Pola Komunikasi Orang Tua Dengan Anak perokok Aktif DI Desa Jembayan Kecamatan Loa Kulu Kabupaten Kutai Kertanegara. Jurnal Imu Komunikasi.

Harahap, Asriana dan Nasution, Latif Kahpi. 2019. Pendidikan Dalam Keluarga. Junal Ilmu- Ilmu Sosial dan Keislaman. Vol. 4.No.4.

H, Tri Utamai, Alfiandra, dan Waluyati, Sri Artati. 2019. Pengaruh Kecerdasan Emosional Terhadap Sikap Peduli Sosial di SMP Negeri 1 Palembang. Jurnal Bhineka Tunggal Ika. Volume 6. Nomor 1. Mei.

Jatmiko, Tri Endang. 2018. Efektivitas Komunikasi Orang Tua Terhadap Kepribadian Intrapersonal Anak. Jurnal Anak Usia Dini dan Pendidikan ANak Usia Dini. Volume 4 Nomor 2 Agusutus.

Kamarusdiana. 2019. Studi Etnografi Dalam Kerangka Masyaraat Dan Budaya. Jurnal Sosial dan Budaya Syar-i. Vol.6.No.2.

Karningtyas, Maria Anggita, Wiendijarti, Ida, dan Prabowo, Agung. 2009. Pola Komunikasi Interpersonal Anak Autis Di Sekolah Autis Fajar Nugraha Yogyakarta. Jurnal IlmuKomunikasi . Volume 7 Nomor 2 Mei-Agustus.

Nasution, Nana Suryana. 2018. Pengembangan Kecerdasan Sosial Melalui Metode Pembelajaran Outdoor Education Dalam Pendidikan jasmani. Vol 6. 
Nikooyeh, Elika Nikooyeh, Fariba Zarani, dan Jalil Fathabadi. 2017. The Mediating Role of Social Skills and Sensation Seeking in the Relationship between Trait Emotional Intelligence and School Adjustment in Adolescents. Journal of Adolescence. Vol. 59. Agustus .

Peyre, Hugo dkk.. 2019. Sex Differences in Psychomotor Development during the Preschool Period: A Longitudinal Study of the Effects of Environmental Factors and of Emotional, Behavioral, and Social Functioning,. Journal of Experimental Child Psychology. Volume 178 Februari.

Putra, Eki Dwi dan Nurthahjanti, Harlina. 2017. Hubungan Antara Kecerdasan Sosial Dengan Organizational Citizenship Behavior Pada Karyawan PT Telkom Indonesia Regional IV Jawa Tengah dan Di Yogyakarta. Jurnal Empati. Volume 6.No.4 Oktober.

Robbiyah, Robbiyah, Ekasari, Diyan, dan Witarsa, Ramdhan Witarsa. 2018. Pengaruh Pola Asuh Ibu terhadap Kecerdasan Sosial Anak Usia Dini di TK Kenanga Kabupaten BandungBarat,. Jurnal Obsesi : Jurnal Pendidikan Anak Usia Dini. Vol. 2. No. 1. 10 Juni.

Rogge,Nicole,,Theesfeld,Insa dan Strassner, Carola. 2019. The Potential of Social Learning in Community Gardens and the Impact of Community Heterogeneity. Learning, Culture and Social Interaction. Jounal homepage.

Rosenberg, Hananel, Ophir, Yaakov dan Asterhan, Christa S.C. 2018. A Virtual Safe Zone: Teachers Supporting Teenage Student Resilience through Social Media in Times of War. Teaching and Teacher Education . Vol. 73 Juli 2018.

Ruminten, I Kadek dan Mastini, Gusti Nyoman Mastini. 2019. Peningkatan MutuPendidikan keluarga Pada Era Milineal. Adi Widya: Jurnal Pendidikan Dasar. Volume 4, No. 2 Oktober.

Sarwinda. 2018. Komunikasi keluarga Dalam Menanamkan Nilai-Nilai Keislaman Pada Rema Desa Tanjung Aman Lampung Utara.Jurnal Al-Bayan. Vol.24.No.1 Januari-Juni.

Schneider, Claudia Schneider dan Madeleine Arnot. 2018.Transactional School-Home-School Communication: Addressing the Mismatches between Migrant Parents' and Teachers' Views of Parental Knowledge, Engagement and the Barriers to Engagement.Teaching and TeacherEducation. Vol.75.Oktober.

Setyowati, Yuli. 2005. Pola Komunikasi Keluarga dan Perkembangan Emosi Anak (Studi Kasus Penerapan Pola Komunikasi Keluarga dan 
Pengaruhnya Terhadap Perkembangan Emosi Anak Pada keluarga Jawa.Jurnal Ilmu Komunikasi. Vol.2.No.1.Juni.

Shao,Meixuan dkk..2019.Distance Perception Warped by Social Relations: Social Interaction Information Compresses Distance.Acta Psychologica.Vol. 202. Januari.

Smith, Lynne Smith, Patrick C.L. Heaven, dan Joseph Ciarrochi.2008.Trait Emotional Intelligence, Conflict Communication Patterns, and Relationship Satisfaction. Personality andIndividual Differences . Vol.44. No. 6. April.

Wolf, Wouter dan Tomasello,Michael Tomasello. 2019.Watching a Video Together Creates Social Closeness between Children and Adults. Journal of Experimental Child Psychology. Vol. 189. Januari .

Enjang. 2009. Komunikasi Konseling. Bandung: NUANSA.

Khairani,Makmun. 2015. Psikologi Komunikasi Dalam Pembelajaran. Yogyakarta: Anggota IKAPI.

Moleong, Lexy J.. 1999. Metode Penelitian Kualitatif. Bandung: PT Remaja Rosdakarya,.

Oktaviana, Clarisa Inda Oktaviana dan Hedi Pudjo Santosa. 2019. Pola Komunikasi Pengasuhan Ibu Single Parent.Jurnal Ilmu Komunikasi.

Rakmat, Jalaluddin. 2011. Psikologi Komunikasi. Bandung: PT Remaja Rosdakarya.

Rahman, Hibana S. 2005. Konsep Dasar Pendidikan Anak Usia Dini. Yogyakarta: Cerdas Pustaka.

Soejanto, Agoes. 2005. Psikologi Komunikasi. Bandung:PT Remaja.

Uno, Hamzah B. 2011. Teori Motivasi \& Pengukurannya. Jakarta: PT Bumi Aksara. 